\title{
Futbol ve Kimlik: K-Pet Süper Lig (KKTC) Takım Armaları Özelinde Bir Analiz
}

\section{Football and Identity: An Analysis on K-Pet Super League (TRNC) Teams' Emblems}

\author{
Ceren Yegen, ${ }^{\mathrm{a},{ }^{*}}$ Metin Karayol ${ }^{\mathrm{b}}$ \\ ${ }^{a}$ Doç. Dr., Mersin Üniversitesi, İletişim Fakültesi, Gazetecilik Bölümü, 33343, Mersin/Türkiye. \\ ORCID: 0000-0001-9582-0711 \\ ${ }^{\text {b }}$ Dr. Öğretim Üyesi, Muş Alparslan Üniversitesi, Beden Eğitimi ve Spor Yüksekokulu, Spor Yöneticiliği Bölümü, 49100, Muş/Türkiye. \\ ORCID: 0000-0003-0809-0410
}

\section{MAKALE BILGIISI}

\section{Makale Geçmişi:}

Başvuru tarihi: 12 Şubat 2019

Düzeltme tarihi: 10 Mayıs 2019

Kabul tarihi: 17 Temmuz 2019

\section{Anahtar Kelimeler:}

Spor, Futbol

Mesaj

Kimlik

KKTC

K-Pet Süper Lig

\section{ARTICLE INFO}

Article history:

Received 12 February 2019

Received in revised form: 10 May 2019

Accepted 17 July 2019

\section{Keywords:}

Sport

Football

Message

Identity

TRNC

K-Pet Super League

\section{ÖZ}

Kamusal gündemde büyük önem taşıyan bir olgu olarak futbol, bir duygudaşlık ilişkisidir. Sporun en çok izlenen türlerinden olan futbol; bireysel, kültürel ve sınıfsal paydaşlıklara da işaret eder. Futbol kulüpleri ilgili paydaşlı̆̆ın bir zeminidir. Futbol kulüpleri armaları ile simgesel mesajlar verir, taraftarın kolektif belleğine seslenirler. Bu armalarda milli kimlik de öne çıkar, armalar kültürel ve tarihsel süreçleri/geçmişi hatırlatır. Bu yüzden armalarda etkili ve retoriği güçlendirici metaforlar kullanılır. Bu çalışmada da Kuzey Kıbrıs Türk Cumhuriyeti (KKTC) K-Pet Süper Lig takımlarının (2018-2019 sezonunda mücadele eden) armaları incelenmiş, kimlik bağlamında ilgili armalardaki kültürel ve nasyonal kodlar ortaya koyulmaya çalışılmıştır. Böylelikle armalarda nelerin öne çıkarıldığı ve hangi değerlere dikkat çekilmek istendiğinin anlaşılması amaçlanmıştır. Çalışmada Hjelmslev'in semiyotik çözümleme modeli kullanılmıştır.

\section{A B S T R A C T}

Football as a phenomenon that has great importance in the public agenda, is a sympathetic relationship. Football is one of the most watched types of sport, also refers to individual, cultural and class partnerships. Football clubs are the basis of relevant partnerships. Football clubs give symbolic messages with their emblems, they address the collective memory of the fan. National identity is also prominent in these emblems, and these emblems recall cultural and historical processes/history. For this reason, effective and rhetoric strengthening metaphors are used in emblems. In this study, the emblems of the Turkish Republic of Northern Cyprus (TRNC) K-Pet Super League teams (Competing in the 2018-2019 season) were examined and the cultural and national codes in the related emblems in the context of identity were put forward. Thus, it is aimed to understand what is highlighted in the emblems and which values are desired to be drawn. In the study, Hjelmslev's semiotic analysis model was used.

\section{Giriş}

En gözde sporlar türlerinden olan futbol, dünyanın hemen her yerinde birçok bireyin gündelik yaşamında, hobileri arasında yer almaktadır. Duygu ortaklığına temellenen futbol, büyük bir sektörü de nitelemektedir ve futbol kulüpleri bu sektörün önemli birer unsurudurlar. Futbol kulüplerinin armalarında kullandıkları argümanlar ise

* Sorumlu yazar/Corresponding author

e-posta: cerenyegen@mersin.edu.tr sembolik birer mesaj vererek, izleyiciyi/taraftarı kolektif bir aidiyete davet eder ve tarihsel ortaklıklardan izler taşır. Bu bağlamda söz konusu armalar için kimliğin göstergesel birer refleksi de denebilir. $\mathrm{Bu}$ yüzden bu çalışmanın konusu, futbol takımı armalarının göstergesel olarak incelenmesidir. Çalışmanın amacı, futbol takımı armaları üzerinden verilen 
sembolik mesajı anlamak ve armalarda öne çıkan kolektif değerleri (kültürel ve nasyonal kodlar vb.) ortaya koymaktır.

Çalışmada, "Futbolda Görsel Kimlik Öğesi Olarak Kulüp Armaları" başlıklı çalışmadan (Çamdereli ve Gürer, 2008) yararlanılmış ve ilgili çalışma gibi Türk futbol kulüplerini ele alan farklı çalışmalar da olduğundan, yargısal örneklem ile bu çalışmanın örneklemi olarak KKTC K-Pet Süper Ligi'nde mücadele eden futbol kulüpleri (16 adet futbol kulübü) belirlenmiştir. Bu seçim ile çalışmanın bir öznellik taşıması da düşünülmektedir ve Türklük bağlamında kolektif milli değerlerin ilgili takım armalarındaki yansımalarının ortaya koyulması beklenmektedir. Çalışmanın analiz kısmında, basit rastlantısal örneklem 1şığında dönemsel seçim olarak, 2018-2019 sezonu tercih edilmiştir. KKTC'de bulunan ve Kıbrıs Türk Futbol Federasyonu bünyesindeki diğer ligler ve farklı sezonlar çalışma kapsamına dâhil edilmemiş, çalışma güncel sezon ile sınırlandırılmıştır. Çalışmanın yöntemi, Hjelmslev'in semiyotik çözümleme modelidir.

\section{Futbol ve Tarihçesi}

Futbol bugün bireylerin kitlesel olarak ilgi gösterdiği popüler bir olgudur. İlk ortaya çıktığı zamandan beri yoğun olarak ilgi gösterilen futbol, ayrıca oldukça büyük bir sektörü de nitelemektedir. Futbol izlerkitlenin keyif aldığ 1 bir uğraştır ve futbol kulüpleri, taraftarlık bağları ve popüler ligler ile adından söz ettirmektedir. Futbolda en büyük gücün, en fazla paraya sahip olan kurumlarla birlikte, en zengin kulüpler, büyük uluslararası federasyonlar ve son on yılda bir buçuk milyona ulaşan televizyon şirketlerinin tekelinde olduğunu iddia eden yaklaşımlar da vardır. Dünyanın en sevilen oyunu olduğu iddia edilen futbolun çağdaş tarihi 100 yıldan fazladır. Her şey, 1863 'te İngiltere'de, rugby futbolu ve dernek futbolunun farklı bağlamlara bölünmesi ve sporun ilk yönetim organı olacak olan Futbol Birliği'nin kurulması ile başlamıştır. Bu bağlamda modern futbolun yaratıcısının 19. yüzyılda en modern ve gelişmiş ülke olan İngiltere olduğu düşünülmektedir. Çünkü ülkenin ekonomik gücü, futbolun evrensel yayılımında da rol sahibi olmuştur. Futbol ilk kez 1900 yılında Paris'teki II Olimpiyat Oyunları'nın programında yer almıştır. Paris Olimpiyatları'nda futbol karşılaşmalarına yaklaşık 300.000 kişi katılım göstermiş, 1928 Amsterdam Olimpiyatları'nda ise futbola Avrupa'dan yoğun talep olmuştur. Tarihsel olarak futbol, Amerika Birleşik Devletleri'nde (ABD) ilkin düşük bir pozisyonda yer almıştır. Zamanla futbol, dünyaya hızlı şekilde yayılmıştır (Baş, 2008; History of Football - The Origins FIFA.com; The Olympic Studies Centre, 2017; Hargrave, 2007: 240; Narcotta-Welp, 2016: 40; Cenikli vd., 2017: 5459).

Giulianotti ve Armstrong'a göre (2010), antik çağlardan beri tarihsel anlayışlar bize, birçok yönden spor, barış ve sosyal uyum arasında önemli bir bağlantı olmadığını da hatırlatır. Sporlar, son derece bölücü veya şiddetli toplumsal tabakalaşma ve dışlama biçimlerinin çoğaltılması için önemli bir sosyo-kültürel alan olarak da kullanılmıştır. Erdoğan'a göre (2008: 4) futbolun örgütlenmiş yapısıyla futboldaki fraksiyonel ilişkiler, profesyonelleşme ile uluslararasılaşma, kapitalist toplumun sömürgen yapısını andırmaktadır. Öyle ki, izlemenin karşılı̆̆ tüketim mallarına ödediği yüksek fiyatlar ile vergilerde kendisini göstermektedir.
Cenikli ve arkadaşlarına göre de (2017: 54-60), futbolun gelişimi ekonomi ve siyaset ile iç içedir. Öyle ki futbol, 19. yüzyılda Sanayi Devrimi neticesinde modernleşirken, I. ve II. Dünya Savaşları arasında siyasileşmiştir. I. Dünya Savaşı'nın ardından futbolu savaşta öğrenen askerler, futbolun popülerleşmesinde rol oynamıştır. 1980 sonrası kendisini gösteren neoliberal politikalar ile ticarileşen futbola yönelik akademik ilgi ise, 1980'li yıllarda artış gösterdiği iddia edilen şiddet ve holiganizm olayları ile fazlalaşmıştır. Dobson ve Goddard ise (2001), profesyonel takım sporlarına yönelik akademik ilginin 1950'lerde başladığı iddiasındadır.

\section{Futbol, Ekonomi ve Küreselleșme}

Erdoğan'a göre (2008: 3) futbol söz konusu olduğunda birey, yalnızca bir oyun ya da seyir sınırı içinde kalmaz; içsel ve dışsal ilişskiler de kurar ve sürdürür. Futbolcular da dâhil birçok birey, aslında futbol ile "rekabetçi bireycilik", "birlik ve beraberlik", "milliyetçilik", "cinsiyet farklılığı" gibi olgulara destek verir. Futbol ayrıca, kitlesel bir reklam aracını da niteler. Devecioğlu ve arkadaşlarının (2012: 35) belirttiği üzere bugün spor kulüpleri, ekonomi ve yönetsel süreç bağlamında birer "işletme anlayışı" içerisindedirler. Ağar'a göre de (2006: 271), toplumsal gündemin ağır toplarından olan futbol sponsorluk, ürün satışı, pazarlama ve reklamcılık özelinde dâhi esaslı bir sektörü simgelemektedir. Sporun bir sektör olarak gelişmesi ve ilerlemesinde büyük rol sahibi olan olguların başında, toplumları birçok açıdan (ekonomik, kültürel, siyasal vb.) kuşatan ve bütünleştirici, “aynı”laştırıcı bir periyodu zorunlu kılan süreçler bütünü olan küreselleşmenin geldiği de belirtilmelidir. Futbolun küreselleşme gibi göç ile de yakından bir ilişkisi vardır. Futbol, göç ve küreselleşme konusundaki tartışmalar 20. yüzyılda tekrar popüler olmuştur (Ustakara ve Aydemir, 2016: 16; Taylor, 2007). Bazı yaklaşımlara göre ise, futbolun tarihsel durumu ve gelişiminin net şekilde anlaşılması, işçi sınıfı ve gündelik hayat kültürüyle bağlantısının araştırılması ile mümkündür. Çünkü modern futbolun ortaya çıkması gibi kurumsallaşması ve yayılmasında da Sanayi Devrimi ile gelişen işçi hareketleri büyük rol oynamıştır. Ayrıca futbolun sınıfsal mücadelede önemli bir araç olarak kullanıldığı da düşünülmektedir (Şahin ve Tunçkol, 2010).

Futbol bugün bir popüler kültür ürünü olarak da sunulmaktadır. Bir futbol liginin kalitesi ilgili ligdeki rekabetçi dengenin mevcut olma durumu ile ilişkili iken, futbol kulüplerindeki sportif başarının derecelendirilmesi ise puantaj sistemi ile sağlanmaktadır (Özdağ vd., 2011; Doğru, 2008; Ulun ve Yetim, 2016: 71-72).

\subsection{Futbolda Bağl1lık, Etnisizm ve Şiddet}

Türkiye'de spor kulüpleri 20. yüzyıl başlarından itibaren kurulurken, ilgili kulüpler 1909 yllında Cemiyetler Kanunu'nun çıkarılmasının ardından resmiyet kazanmışlardır. Söz konusu spor kulüpleri atletizm, eskrim, güreş, jimnastik gibi birçok farklı branş ile sportif bir çeşitliliği de sunmuş, ilk spor kulüpleri ilkin gayrimüslimlerce kurulmuştur. İstanbul'da kurulan Moda, Elpis, Imogene ve Kadıköy (Union) adlı İngiliz ve Rum takımları 1904'de kendi aralarında "İstanbul Futbol Birliği" adlı bir lig kurmuş, Galatasaray ilgili lige 1905 yılında katılırken, Fenerbahçe ise 1908 yılında katılmıştır. 1910'da 
ligdeki takım sayısı artması ile gözlenen problemler sebebiyle lig, "İstanbul Futbol Kulüpleri Ligi” ismi ile yeniden örgütlenmiş ve "Pazar" ile "Cuma" ligi şeklinde ikiye ayrılmıştır (Günay, 2016: 383).

Çağdaş toplumlarda, sporun tüketicileri olan seyirciler büyük önem sahibidir (Soygüden vd., 2016). Seyirciler ve sporcular ile birlikte taraftarlar da sporun önemli bir unsurudur. Bir terim olarak "taraftar", "bir spor kulübüne bağlı olan, onunla ilgilenen, onu destekleyen" bireyleri ifade etmek için kullanılmaktadır. Giulianotti taraftar tiplerini şöyle sınıflandırmaktadır (Baş, 2008: 33-39):

1. Sadık taraftar,

2. İzleyici-taraftar,

3. Hayranlar (Fan),

4. Gezginci taraftar (Flaneur)

Futbolda taraftar topluluklarını Anderson'un millet yaklaşımı temelinde olan "hayali cemaat" kavramı çerçevesinde değerlendiren bir araştırma, dikkat çekici veriler sunmaktadır. "Ankaragücü” futbol takımının üç taraftar grubu ile gerçekleştirilen araştırmada, "taraftar topluluklarının birer hayali cemaat olarak kuruldukları ve topluluk üyelerinin taraftar kimliğine bağlılığının bununla ilişkili olduğu" sonucuna varılmıştır (Hacısoftaoğlu vd., 2012).

Aşırı bağlılık ve sadakat bağlamında öne çıkan "holiganlar" ve "fanatikler" de önemli taraftar nitelemeleridir. Cenikli ve arkadaşlarına göre (2017: 54), futbol fair play temelinde yaygınlaşmalı ve şiddetten, terörizmden uzak olmalıdır. $\mathrm{Ne}$ yazık ki şiddet/sporda şiddet, ulusal ya da uluslararası müsabakalarda sıklıkla gözlenen ve önüne geçilmesi noktasında acilen tedbirler alınması gereken bir durumdur.

Özsoy’un (2011) “Spor Gazetelerinin Başlıklarında Militarist ve Şiddet İçerikli Metaforlar” başlıklı çalışması ise spor ve şiddete farklı bir özne temelinde yaklaşmaktadır. Özsoy, yazılı basın temelinde militarist ve şiddet unsuru içeren anahtar kelimeden yola çıkarak bazı spor gazetelerini incelemiştir. İncelemeye göre, haber ve yorum başlıklarında en fazla "savaş" ve "kavga" kelimelerinin yer aldığ saptanmıştır. Haberlerde anlaşmazlıklar genellikle "kavga", müsabakalar ise "kapıșma" şeklinde nitelenmiștir. Özsoy’a göre, medyanın bir kolu olarak spor medyası misyonu gereği mecazen de olsa şiddeti anımsatan ifadelerden kaçınmalıdır.

Futbol konusundaki önemli tartışmalardan biri de ırkçılık, ayrımcılık konusundadır. Bazı yaklaşımlara göre futbol etnik, dini ya da kültürel kimlikleri referans alarak bir "ötekileştirme aracı" misyonu görmektedir (Agos Gazetesi, 24.02.2009). Zelyurt'a göre de (2013: 180-210), bir toplumdaki etnik, dini ya da kültürel karşıtlık ve anlaşmazlıkların yansımaları futbol olgusunda da görülebilir. Yer yer bir karşıt kimlik olarak gelişen futbol, yer yer bir kamplaşma aracına da dönüşebilir. Bu duruma kolonyalizm döneminde Hintliler'in futbolu milliyetçi, sosyal ve bölgesel kimliklere dikkat çekmek için kullanmaları örnek olarak verilebilir. Etnik kimlik futbol bağlamında bir ötekileştirme aracı olmamalıdır (Agos Gazetesi, 24.02.2009). Etnisite kültürel farklılığı niteler ve milli ulusal kimliğin bir unsurudur. Ancak kesinlikle etnik kimlik, ulusal/milli kimlik ile aynı şey değildir ve etnik kimlik talihsiz şekilde sıklıkla ırkçılık ile milliyetçilik temelinde tartışılmaktadır (Calhoun, 2012; Smith, 1992; Yegen, 2018).

\section{Tasarım ve Logo}

Güzel sanatlar, doğa bilimleri ya da en yakın zamanda sosyal bilimlerde tasarım düşüncesinin temellerini keşfetme çabalarına karşın, tasarımın tek bir tanımı olmadığı görülmüştür (Buchanan, 1992: 5). Ünlü tasarımcı Charles Eames kendisiyle yapılan bir görüşmede, sizin tasarım tanımınız nedir? sorusunu, "Öğeleri belirli bir amaca en iyi şekilde uyacak şekilde düzenlemek için bir plan” şeklinde yanıtlamıştır. "İhtiyaçları karşılayan mal ve hizmetlere şekil vermek" (Ulrich, 2011: 394) olarak tanımlanan tasarım kelimesi, çeşitli toplumsal bağlamlarda, örneğin kariyer tasarımı, yemek tasarımı ve topluluk tasarımı gibi giderek artan birçok çeşitlilikte kullanılmaktadır (Taura ve Nagai, 2009). Çünkü insan uzun yıllar boyunca arzu ve ihtiyaçları doğrultusunda çeşitli tasarım araçları üretmiştir (Enes, 2011: 1). Tasarım sürecinin ya adım adım ya da daha fazla sezgisel biçimde ilerlediğini iddia eden yaklaşımlar da vardır. Tasarım süreci nasıl olursa olsun, kuşkusuz kalbinde ve odağında "yaratıcılık" vardır ve yaratıcılık aslında oldukça geniş bir bakış açısıdır (Pontious, 2013: 3).

Tasarım bağlamında beklenti, ilgi çekicilik ve özerklik gibi kavramlar önemlidir (Zamenopoulos ve Alexiou, 2007: 413). Tasarım araştırması bağlamında öne çıkan bazı teoriler de vardır ve bunlar; "Tanımlayıcı Tasarım Teorileri", "Sınırlayıcı Tasarım Teorileri" ve "Önleyici/Kuralcı Tasarım Teorileri”dir (Vermaas, 2014: 47-50). İlgili teoriler özetle tasarım sürecindeki amaç/hedef, kapsam ve sınırlılıklara odaklanma amacındadır. Bu noktada çok sayıda yazarın tasarım araştırmasını, "hem tasarım çalışması hem de tasarım eylemiyle ortaya çıkan bilgi üretim süreci” olarak ifade ettiğini de belirtelim (Faste ve Faste, 2012).

Logo ise, tanımlayıcı bir semboldür. Logolar organizasyon, ürün, marka veya fikrin kimliğini temsil eder. Logo basit/anlaşılır, geniş ve küçük ölçekte olan siyah ya da beyaz olsa da etkili bir tasarımdır (Logo Design Basics, Erişim: Ekim, 2018). Logo aslında müşterilerin ürünleri hızlı şekilde tanıması için kullanılan ya da ürünlerin/işletmelerin bazı değerlerini aktarmak için oluşturulan grafik tasarımdır. Logo markayı temsil eder, görsel kimlik yaratır; ancak kendi başına bir marka değildir. Logolar basit veya karmaşık olabilir. Bazen bir logo sadece belirli bir yazı tipi veya renkli yazı stili kullanan şirket adıdır, bazen ise Apple için bir ısırık eksik olan elmada olduğu gibi, ana şirket logosudur (Cornell Maple Bulletin 103, 2007; Hardy, 2011). Logo programlama dili ise çok farklıdır. Logo bir tasarıma yerleştirildiğinde, ona "net alan" verilmeli ve doğru/kaliteli bir tasarım yapılmalıdır (Papert, 1999; Pearson Guidelines 2016; Year Of Light, 2015).

Bir logo okunabilir, anlaşılması kolay, uyarlanabilir, tekrarlanabilir, unutulmaz, zamansız ve basit olmalıdır. Logonun gücü, ürünlerin kalitesini ve değerini garanti eder. Logonun işlevleri rasyonel ve duygusaldır ve aşağıdaki gibi sıralanmıştır (Adir vd., 2012: 651):

1. İrtibat Fonksiyonu (halkla iletişimi sağlar ve sürdürür)

2. Açıklama Fonksiyonu (organizasyonun kimliğini ve kişiliğini belirler)

3. Düzanlamsal Fonksiyon (ürün/hizmet/olay hakkında bilgi sunar) 
4. Tanımlama Fonksiyonu (hedef kitleyi gösterir)

5. Signifikasyon Fonksiyonu (duygusal değerlendirme sağlar)

6. Çeviri Fonksiyonu (mesajın kodunu açıklar)

7. Estetik Fonksiyonu (zevk, duyarlılık ilhama işaret eder)

\subsection{Görsel Kimlik Bağlamında Futbol Kulübü Armaları}

Kimlik çağdaş toplumlarda önemli bir kavram olarak ele alınır. Bazı yaklaşımlara göre "tahsis edilen”, bazı yaklaşımlara göre ise "seçilen" bir olgu olarak kimlik (Howard, 2000: 367), bireyin kim ya da ne olduğu üzerine düşünmesine işaret etmektedir. Bauman, kimliğin zamansal ilişkiler, geçmiş, şimdiki zaman, gelecek temelinde sosyal alanda yaratıldığını hatırlatır (Kehily, 2009). Dolayısı ile kimlik ve benlik kavramları bireyin içsel ve dışsal sürecinde gelişen ve şekillenen olgulardır.

Milli (ulusal) kimlik ise geniş kolektif aidiyetine işaret eder ve oldukça tartışmalı bir konudur. Kimlik sporda birçok türde önemli bir unsurdur. Örneğin uluslararası mücadeleler milli kimliği öne çıkaran propaganda faaliyetleri (beyaz) noktasında ele alınabilir. Çünkü ilgili mücadelelere ve sporculara nasyonal bir misyon yüklenir. Spor bu bağlamda milli bir güç gösterisini de niteler (Şahin, vd., 2010; Yegen, 2018). Bazı yaklaşımlara göre futbol, milli kimliklerin oluşumunda etkinlik, güç ve karşıtlık noktasında rol sahibidir (Agos Gazetesi, 24.02.2009). Celtic kulübünün İskoçya'daki İrlandalı kimliğini temsil etmesi bu iddiaya verilebilecek bir örnektir (Zelyurt, 2013).

Futbol bağlamında kulüplerin armaları da kimliğin görsel formuna işaret eder. Bu armalar çeşitli değerler, etkenler ve unsurlar çerçevesinde oluşturulmuşlardır ve dolayısı ile kültürel elementler taşıdıkları gibi, bir kimlik biçiminin simgeleyicisi de olabilirler. Çamdereli ve Gürer'e göre de (2008: 135), futbol kulüp armaları büyük simgesel değerler taşımaktadırlar ve başlı başına görsel anlatım aracıdırlar. Armalar çeşitlilik gösteren renk, tasarım ve hikâyeler ile oluşturulmaktadırlar. Spor kulüpleri birer "marka" olarak düşünüldüğünde kurumsal kimliklerini öne çıkaran bir olgu olarak armaların, logoların büyük önem taşıdığı görülür. Çünkü arma markanın akılda kalmasını sağladığı gibi, etkileyicidir de ve aslindan sportif aidiyeti de simgelemektedir (Ustakara ve Aydemir, 2016: 16). Bugün birçok firma kurumsal kimlik oluşturmaya çalışırken, birçoğu da küreselleşme, teknoloji ve yeni hedef kitle özellikleri temelinde kurumsal kimliklerini güncellemektedir. Dikkat çekici tasarımlar, akılda kalıcı logolar öne çıkmakta; hedef kitlenin kolektif belleğinde yer etme çabası gösterilmektedir (Topçu, 2017: 157).

\subsection{KKTC K-Pet Süper Lig Takım Logoları Üzerine Bir İnceleme}

Bu kısımda Kuzey Kıbrıs Türk Cumhuriyeti (KKTC) K-Pet Süper Lig'inde mücadele eden 16 futbol kulübünün armaları incelenmiş; kimliğin hangi formalarının yansıtıldığı, yer verilen değerler ve kültürel unsurlar ortaya koyulmaya çalışılmıştır.

\subsubsection{Evren ve Örneklem}

Çalışmanın evreni, Kıbrıs Türk Futbol Federasyonu bünyesinde olan KKTC futbol kulüpleridir. Örneklem ise 2018-2019 sezonunda K-Pet Süper Lig'de mücadele eden 16 adet futbol kulübüdür. Örneklem olarak seçilen futbol kulüpleri şunlardır: BAF ÜLKÜ YURDU, BINATLI YSK, CIHANGİR GSK, ÇETINNAYA TSK, DOĞAN TÜRK BİRLİĞİ SK, ESENTEPE KKSK, GENÇLIKK GÜCÜ TSK, GIRNE HALK EVİ, GÖNYELİ SK, KÜÇÜK KAYMAKLI TSK, L. GENÇLER BİRLİĞI SK, LEFKE TSK, MAĞUSA TÜRK GÜCÜ, MERİT ALSANCAK YEŞILIOVA SK, TÜRK OCAĞI LIMASOL ve YENICAMİ AK.

\subsubsection{Kapsam ve Sinırlilık}

Çalışmanın analiz kısmı, KKTC K-Pet Süper Lig'inde mücadele eden 16 futbol kulübünün armalarının incelenmesini kapsamaktadır. Çalışma K-Pet Süper Lig takımları ve 2018-2019 sezonu ile sınırlandırılmış; diğer ligler ve sezonlar elde edilecek veriler noktasında sınırlılık sağlamak amacıyla kapsam dışı bırakılmıştır. Futbol kulüplerinin analiz sıralaması alfabetik sıraya göre yapilmıştır.

\subsubsection{Yöntem}

Göstergelerin anlamları konusunda çok uzun yıllardan beri kafa yorulmaktadır. Ortaya çıkışından beri çok tartışılan ve gelişen göstergebilim ise gösterge-gösteren ve gösterilen arasındaki ilişkiyi kavramayı amaçlayan bir yöntemi niteler ve birçok alanda verilmek istenen mesajı etkili şekilde ulaştırır. Hjelmslev’e göre göstergesel sistemde içerik, ifade gibi unsurlar önem taşır ve semiyotik ile semiyotik kabulleri birbirleriyle ilişkili olarak ifade edilmelidir (Yılmaz ve Saymal1, 2013: 168; İlkdoğan, 2017: 3150; Badir, 2014).

Çalışmada Hjelmslev'in "eşbiçimli düzende çözümleme" tekniği kullanılmış, ayrıca bu çalışma ile benzerlik taşıyan Çamdereli ve Gürer'in (2008) "Futbolda Görsel Kimlik Öğesi Olarak Kulüp Armaları” başlıklı çalışmasından yararlanılmıştır. "Anlatımın biçimi ya da sözcelem düzeyi (sınırlar, yüzey, renksel örüntü)" ile "İçeriğin biçimi ya da anlamlama düzeyi (sınırlar, yüzey, renksel örüntü)", analizin temelini oluşturmaktadır. Anlatımın biçimi ya da sözcelem düzeyinde sınırlar tasarımsal çerçeveyi, yüzey biçimsel göndergeler bütününü, renksel örüntü ise renksel anlatı birimlerini niteler. İçeriğin biçimi ya da anlamlama düzeyinde sınırlar ise kavramsal alanı çevreleyen işlevsel içerikbirimleri, yüzey biçimlenmiş değerler bütününü, renksel örüntü de renksel içerikbirimleri niteler (Çamdereli ve Gürer, 2008: 143). Hjelmslev'in yaklaşımında, "gösteren" ile "gösterilen" kavramları yerine, "anlatım" ve "içerik" kavramları söz konusudur. Hjelmslev'in yaklaşımında tıpkı Saussure'un yaklaşımında olduğu gibi önemli olan "biçimler”dir (Bayat, 2010: 157-158). 


\subsubsection{Analiz}

\section{BAF Ülkü Yurdu}

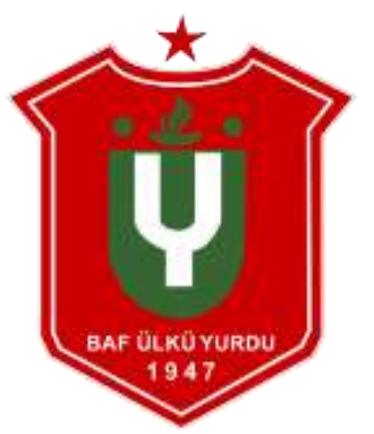

Armada sol, sağ ve alttan sivrilmiş bir forma formu vardır. Yüzeyde futbol kulübünün adı, yıl (1947), meşale benzeri bir çizim dikkat çekmektedir. Armaya kırmızı ve beyaz renk birimler egemen iken, yeşil renk de görülmektedir. Keskin formlar ve meşale çizimi ateşin gücünü, zaferi ortaya koymakta, dikkat çekicilik sağlamaktadır. Meşale Yunan mitolojisinde Eros ve Afrodit'i temsil etmekteydi ve anlamı aşk idi. Meşale, Hristiyanlıkta ise dünyayı aydınlatan Tanrı'nın ruhunu sembolize etmektedir. Ayrıca meşalenin 1şı̆̆1 dünyaya iyiliği yayan bir sembol olarak kabul edilmektedir (http://www.hurriyet.com.tr, 12.08.1997). Forma formu sporu simgelerken, formanın üzerinde yer alan yıldız ve ona yatay olarak bakan yumuşak hatlı yarım hilal, Türk bayrağını simgelemektedir. Kırmızı gücü, ateşi; beyaz saflığı, temizliği simgelemektedir. Kırmızı-beyaz Türklüğü (milliliği) ise yeşil verimlilik, yenilenme ve barışı simgelemektedir (Çavdar, 2007). Logodaki renk zıtlığı da dikkat çekicidir.

\section{Binatlı YSK}

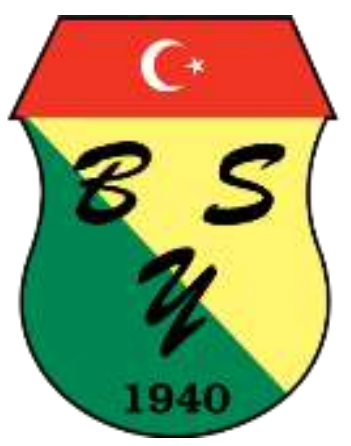

Armada üst, sol ve sağda sivrilmiş bir forma formu var iken, alt kısım yumuşak şekilde yuvarlanmıştır. Yüzeyde B, S ve Y harfleri ile yıl (1947) ve üst kısımda ay-yıldız formu dikkat çekmektedir. Armaya yeşil ve sarı renk birimler egemen iken, kırmızı-beyaz ve siyah da görülmektedir. Daha fazla dikkat çeken yumuşak geçiş, yalın bir anlamlama düzeyini göstermektedir. Sivri hatlar ise dikkat çekicilik sağlamıştır. B, S ve Y harfleri Binatlı Yılmaz Spor Kulübü’nün kısaltmasını nitelerken, üst kısımdaki Türk bayrağı milliliği, Türklüğü simgelemektedir. Renkbirimlerden kırmızı-beyaz Türklüğü (milliliği); yeşil verimlilik, yenilenme ve barışı; sarı aydınlık ve özgüveni; siyah ise ciddiyet ve ağırbaşlılığ 1 simgelemektedir (Çavdar, 2007).

\section{Cihangir GSK}

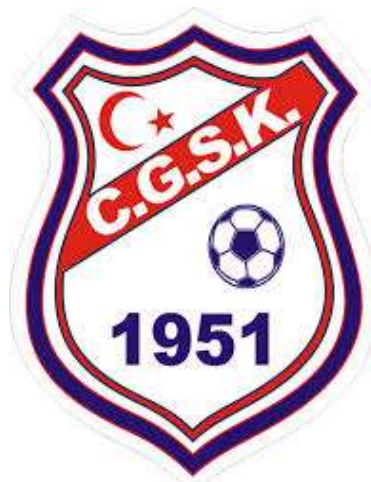

Üst ve alt kisımda keskin, ortada yuvarlak hatlar baskındır. Yüzeyde C.G.S.K. harfleri, y1l (1951) ve futbol topu görünmektedir. Beyaz, lacivert ve kırmızı egemen renkbirimlerdir. Daha fazla dikkat çeken yumuşak geçiş, yalın bir anlamlama düzeyini göstermektedir. Sivri hatlar ise armayı dikkat çekici kılmıştır. C.G.S.K, Cihangir Gençlik Spor Kulübü'nün kısaltmasıdır. Futbol topu futbol kulübünü, ay-yıldız ise Türklüğü (milliliği) nitelemektedir. Beyaz renk saflığı, temizliği; kırmızı cesaret ve gücü, lacivert konsantrasyon, düşünce, sezgi, otorite ve sonsuzluğu nitelemektedir (Çavdar, 2007; Doğan, 2017).

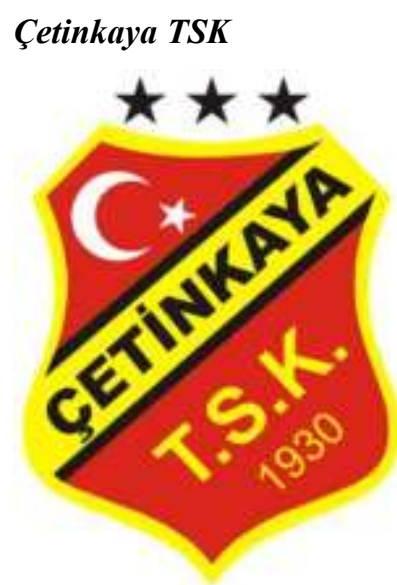

Üst ve alt k1sımda keskin, ortada yuvarlak hatlar baskındır. Yüzeyde ÇETINKAYA yazısı, ayyıldız formu, T.S.K. yazisı ve yil (1930) yer almaktadır. Armaya kırmizı ve sarı renkler egemendir. Beyaz ve siyah renkler de mevcuttur. Armadaki yumuşak geçiş yalın bir anlamlama düzeyini göstermekte, sivri hatlar ise dikkat çekicilik sağlamaktadır. T.S.K, Türk Spor Kulübü'nün kısaltmasıdır. Sol üst kısımda yer alan ayyıldız Türklüğü (milliliği) simgelemektedir. Kırmızı-beyaz renkler Türklüğü, sarı aydınlık ve özgüveni; siyah ise ciddiyet ve ağır başlılığı sembolize etmektedir (Çavdar, 2007).

\section{Doğan Türk Birliği SK}

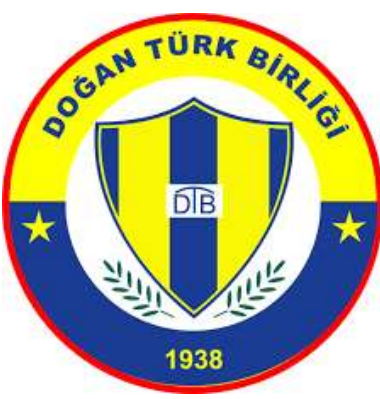

Kırmızı ince bir çizgi ile sınırlandırılmış kırmızı bir daire/yuvarlak form mevcuttur. İçerisinde üst kısımları sivri bir üçgenimsi form vardır. Yüzeyde Doğan Türk Birliği yazısı, DTB yazıs1, yıldız ve yaprak (defne) formları görülmektedir. Armada sarı ve lacivert renkbirimler baskındır. Kırmızı, beyaz, yeşil renkler de vardır. Yumuşak hatlar anlamlama düzeyini fonksiyonel kılmıştır. DTB, Doğan Türk Birliği'nin kısaltmasıdır. Türklerin ilk dini Şamanizm'de de önemli bir form olan yıldız Türklüğü simgelerken (Saraçoğlu, 2007: 2670-2672), yaprak (defne) 
formu barışı, zaferi simgelemektedir (Şahindoğan, 2017). Baskın renkbirimlerden olan sarı özgüven ve heyecanı/aydınlığı, lacivert kararlılık ve konsantrasyonu simgelemektedir. Beyaz renk saflığı ve temizliği, yeşil renk ise barış ve verimliliği simgelemektedir (Çavdar, 2007; Doğan, 2017).

\section{Esentepe KKSK}

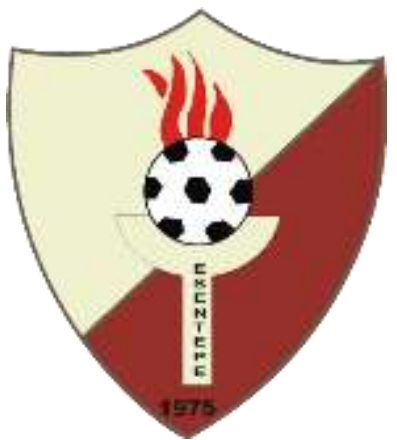

Yukarı kısım sivri iken, aşağıya doğru yuvarlak hatlar (siyah renk ile çerçevelenmiş) geliştirilmiş; en alt kısım sivriltilmiştir. Yüzeyde bir meşale, futbol topu ve ESENTEPE yazısı ile yıl (1975) görünmektedir. Baskın renkler kirmizı, beyaz ve siyahtır. Sivriden yuvarlağa doğru gelen hatlar, anlama düzeyini fonksiyonel kılmaktadır ve dikkat çekicidir. Meşale ateşin gücünü, zaferi ortaya koymaktadır. Meşale Yunan mitolojisinde Eros ve Afrodit'i temsil etmekteydi ve anlamı aşk idi. Meşale, Hristiyanlıkta ise dünyayı aydınlatan Tanrı'nın ruhunu sembolize etmektedir. Ayrıca meşalenin 1şığı dünyaya iyiliği yayan bir sembol olarak kabul edilmektedir (http://www.hurriyet.com.tr, 12.08.1997). Kırmızı-beyaz Türklüğü (milliliği) simgelerken, siyah ciddiyet ve ağırbaşlılığ 1 simgelemektedir (Çavdar, 2007).

\section{Gençlikgücü TSK}

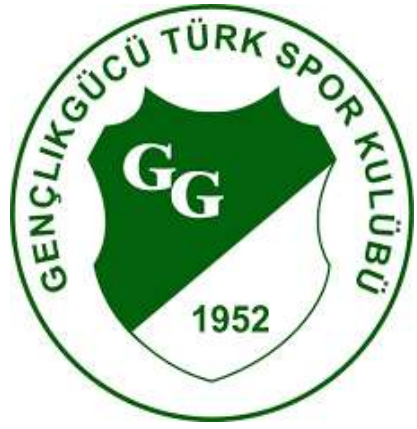

Yeşil ile çerçevelenmiş yuvarlak bir daire görülmektedir. Yüzeyde GENÇLIKGÜCÜ TÜRK SPOR KULÜBÜ yazıs1, GG harfleri, y1l (1952) yer almıştır. Yalnızca yeşil ve beyaz renkler hâkimdir. Daire şeklindeki arma, içeriğin biçimini fonksiyonel kılmıştır.

GG Gençlikgücü'nün kısaltmasıdır. Yuvarlak ve yer yer keskin hatlarla çizilmiş forma sporu/futbolu simgelemektedir. Beyaz saflığı, temizliği; yeşil ise barış ve verimliliği, yenilenmeyi simgelemektedir (Çavdar, 2007).

\section{Girne Halkevi}

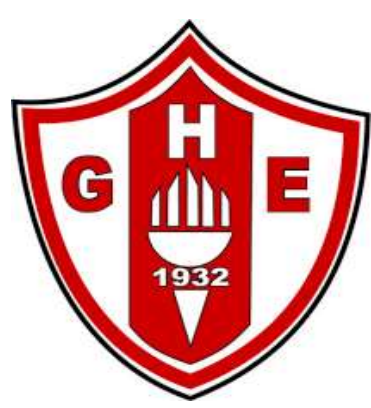

Üst ve alt sivrilmiş, orta kısım yuvarlaklaştırılarak yumuşatılmıştır. Yüzeyde $\mathrm{G}, \mathrm{H}$ ve E harfleri, y1l (1932) ve meşale görülmektedir. Armaya kırmızı ve beyaz renkbirimler hâkimdir. Armayı çerçeveleyen renk siyahtır. Sivri ve yuvarlak hatlar içeriğin biçimini fonksiyonel kılmıştır. G,H,E
Girne Halkevi’nin kısaltmasıdır. Meşale ateşin gücünü, zaferi ortaya koymaktadır. Meşale Yunan mitolojisinde Eros ve Afrodit'i temsil etmekteydi ve anlamı aşk idi. Meşale, Hristiyanlıkta ise dünyayı aydınlatan Tanrı'nın ruhunu sembolize etmektedir. Ayrıca meşalenin ıșı̆̆ı dünyaya iyiliği yayan bir sembol olarak kabul edilmektedir (http://www.hurriyet.com.tr, 12.08.1997). Baskın renkbirimler olan kırmızı ve beyaz Türklüğü (milliliği) simgelemektedir.

\section{Gönyeli SK}

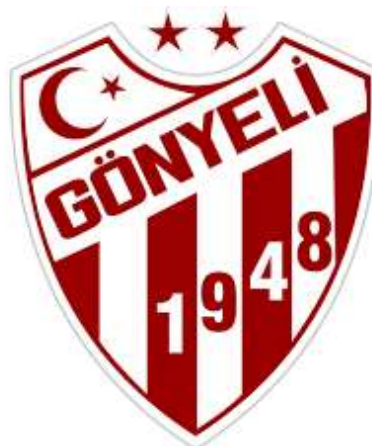

Armada üst iç ve dış kısımlar sivriltilmiş, orta k1sim

yuvarlaklaştırılmıştır. Yüzeyde ay-yıldız formu, GÖNYELİ, yazıs1, yıl (1948) ve uzun-kısa kalın şeritler mevcuttur. Armaya kırmızi-beyaz renkbirimler hâkimdir. Armada yukarı kısımdaki sivrilik yatay bir hilal oluşturmuş, üzerindeki yıldız imgesi ile (renkler de bağlamında) Türk bayrağı simgelenmiştir. Armanın sol üst kısmında yine Türklüğe dikkat çeken ay-yıldız formu görünmektedir. Kırmızı-beyaz renkbirimler Türklüğü (milliliği) sembolize etmektedir.

\section{Küçükkaymaklı TSK}

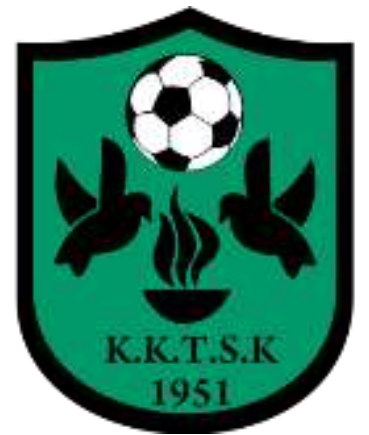

Armada sol, sağ ve üst kisimlar sivri iken, yoğunluk yuvarlatılmış formdadır. Yüzeyde K.K.T.S.K yazıs1, yıl (1951), iki (2) güvercin, futbol topu ve bir meşale görünmektedir. Baskın renkler yeşil ve siyahtır. Beyaz renk de mevcuttur. Daha fazla göze çarpan yuvarlak hatlar, içeriğin biçimini fonksiyonel kılmıştır. K.K.T.S.K. Küçükkaymaklı Türk Spor Kulübü'nün kısaltmasıdır. Meşale ateşin gücünü, zaferi ortaya koymaktadır. Meşale Yunan mitolojisinde Eros ve Afrodit'i temsil etmekteydi ve anlamı aşk idi. Meşale, Hristiyanlıkta ise dünyayı aydınlatan Tanrı'nın ruhunu sembolize etmektedir. Ayrıca meşalenin ışığı dünyaya iyiliğgi yayan bir sembol olarak kabul edilmektedir (http://www.hurriyet.com.tr, 12.08.1997). Bununla birlikte yüzeyde yer alan güvercinler de barışı simgelemektedir. Güvercin Türk mitolojisinde ruhun simgesidir ve Türkİslam anlayışı ile Anadolu'da ayrı bir öneme haizdir. Zenginlik ve bolluk getiren güvercin, rüya tabirlerinde müjdenin habercisi konumundadır. Hristiyanlıkta beyaz güvercin ise "Kutsal Ruh"u yani "Tanrı'nın Ruhu”nu sembolize etmektedir (Şişci, 2018: 52-53; Boztaş ve Düz, 2014: 323). Yeşil renk barış ve verimliliğe, siyah ise ciddiyet ve ağırbaşlılığa gönderme yapmaktadır (Çavdar, 2007). 


\section{Larnaka Gençler Birliği TSK}

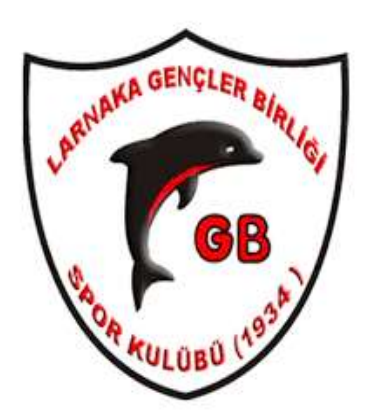

Armanın sol ve să̆ üst kısımları sivriltilmiş iken, aşağıya doğru yuvarlaklaştırılarak inen hatlar, sivri şekilde son bulmuştur. Hatlar siyah renkbirim ile çerçevelenmiştir. Yüzeyde Larnaka Gençler Birliği Spor Kulübü yazısı, $G$ ve $B$ harfleri, yunus görseli ve yıl (1934) bulunmaktadır. Baskın renkler siyah, kırmızı ve beyazdır. Yuvarlak hatlar, içeriğin biçimini fonksiyonel kılarken, sivri hatlar dikkat çekicilik sağlamıştır. G ve B harfleri, Gençler Birliği'nin kısaltmasıdır. Armada kullanılan yunus kurtuluşu ve zaferi simgelemektedir (Üzmez, 2016). Yunus betimi, Erken Hristiyanlıkta ise hem Eski hem de Yeni Ahit ile ilişkilidir ve Eski Ahit konuları arasında "Yunus Öyküsü" bulunmaktadır (Y1lmaz, 2016: 758). Kırmızı-beyaz renk Türklügüu, siyah renk ise ciddiyet ve ağırbaşlılığı simgelemektedir (Çavdar, 2007).

\section{Lefke TSK}

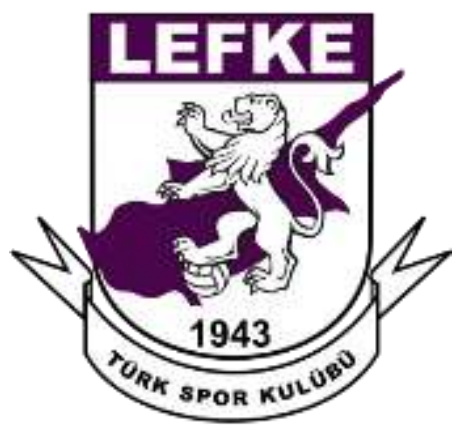

Armaya dikdörtgen form hâkim iken, alt kısmın yuvarlaklaştırıldığ görülmektedir. Yüzeyde LEFKE Türk Spor Kulübü yazısı, y1l (1943), bir aslan (ayağında futbol topu var) ve bir harita görülmektedir. Baskın renkler mor ve beyazdir. Siyah renkbirim ise çerçevede ve bazı yazılarda kullanılmıştır. Yüzeyde yer alan harita Kuzey Kıbrıs Türk Cumhuriyeti'ni, aslan ise güç ve cesareti sembolize etmektedir. Ezoterizme göre de aslan "ilahi idare"nin sembolüdür. Mesnevi'de ise aslan "mürşid" ya da "İnsan-1 Kamil"i simgelemektedir. Beyaz renk saflığı/temizliği simgelerken, mor renk ise güç ve huzuru simgelemektedir (misirgizemleri.blogspot.com, 2008; Nur, 2013: 22; Çavdar, 2007).

\section{Mağusa Türk Gücü}

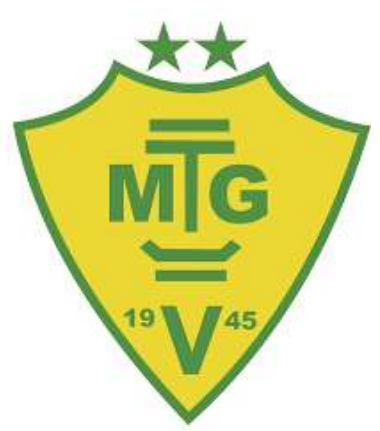

Armaya yeşil renk ile çerçevelenmiş keskin sınırlar hâkimdir. Yüzeyde MTG harfleri, V harfi, y1l (1945) ve iki tane yıldız görülmektedir. Armada kullanılan renkler yeşil ve sarıdır. Sarı renk yeşile oranla daha baskındır. Sivri formlar, armayı dikkat çekici kılmıştır. Armada üst kısımda yatay bir hilal çizimi görülmektedir. İlgili hilalin üzerinde yer alan y1ldız ile ay-yıldız formu yaratılmaya çalışılmıştır. MTG Mağusa Türk Gücü'nün kısaltmasıdır. Baskın renk olarak göze çarpan sarı özgüven, aydınlık ve heyecanı simgelerken; yeşil ise barış, yenilenme ve verimliliği simgelemektedir (Çavdar, 2007).

\section{Merit Alsancak Yeşilova SK}

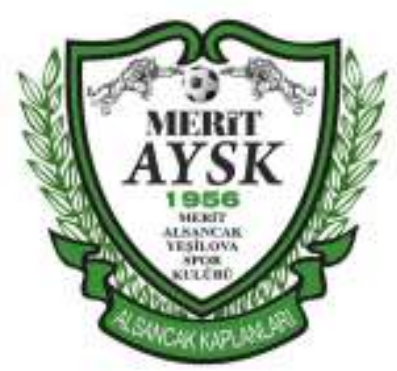

Armada sol ve sağ üst ile alt kisminda sivri form dikkat çekmektedir. Orta k1sim yuvarlak bir forma getirilmiştir. Yüzeyde MERITT AYSK yazısı, 2 tane kaplan, bir futbol topu, y1l (1956), Merit Alsancak Yeşilova Spor Kulübü ve Alsancak Kaplanları yazısı yer almaktadır. Ayrıca arma çerçevesinin kenarında yapraklar görülmektedir. Armadaki baskın renkler, yeşil ve beyazdır. Armanın çerçeve/sınır rengi ise siyahtır. Sivri hatlar armayı oldukça dikkat çekici kılarken, arma görece kalabalıktır. MERIT AYSK yazısı, Merit Alsancak Yeşilova Spor Kulübü'nün kısaltmasıdır. Armada görülen bir futbol topuna atlayan iki kaplan dikkat çekicidir. Çünkü kaplan güç ve yiğitliği sembolize etmektedir (Çatalbaş, 2011: 51). Armanın kenarında yer alan yapraklar (defne) ise barışı, zaferi simgelemektedir (Şahindoğan, 2017). Armada baskın olan yeşil renk verimlilik, yenilenme ve barış1; siyah renk ise ciddiyet ve ağırbaşlılığı simgelemektedir.

\section{Türk Ocă̆ı Limasol}

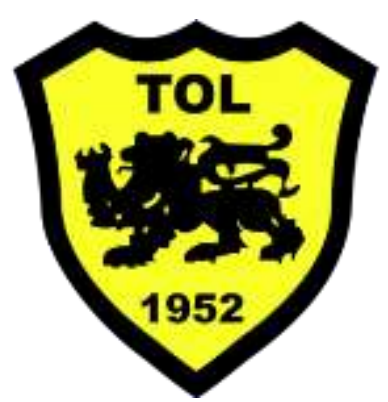

Armaya sivri hatlar egemendir. Armanın çerçevesi kalın siyah şerit ile sınırlandırılmıştır. Yüzeyde TOL yazıs1, y1l (1952) ve ayağında krampon bulunan karmaşı bir aslan görseli (aslan \& akrep karması gibi) yer almaktadir. Armadaki baskın renkler, sarı ve siyahtır. Sarı, siyaha nazaran daha baskındır. Sivri hatlar armayı dikkat çekici kılmaktadır. TOL Türk Ocağı Limasol'n kısaltmasıdır. Yüzeyde görünen aslan gücü, kuvveti sembolize ederken (Öney, 1992), armada kullanılan renklerden sarı özgüven, aydınlık ve heyecanı; siyah ise ciddiyet ve ağırbaşlılığ 1 simgelemektedir (Çavdar, 2007). 


\section{Yenicami AK}

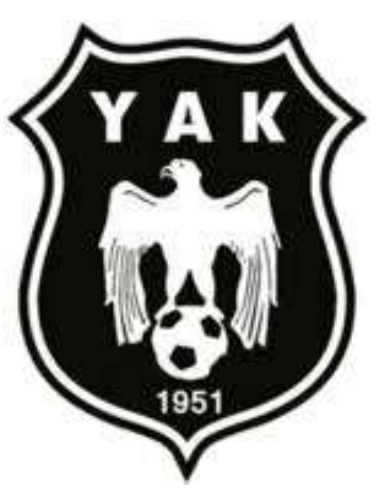

Armaya üst, üst kenar ve alt kısımda hâkim olan sivri form egemendir. Armanın orta kismı yuvarlak bir formda iken, yüzeyde YAK yazısı, yıl (1952), bir futbol topu üzerinde kartal görseli yer almaktadır. Dikkat çeken sivri hatlar, armayı fonksiyonel kılmıştır. Yüzeydeki YAK yazısı Yenicami Ağdelen Kulübü'nün kısaltmasıdır. Baskın renkler siyah ve beyazdır. Yüzeyde yer alan futbol topu üzerinde yer alan kartal koruyuculuk, güç ve hukuku sembolize etmektedir. Kartal figürü, Türk kültüründe önemli bir yerdedir ve Türklerin (tek ya da çift başlı kartal sembolü birçok Türk eserinde dikkat çekmektedir) milli sembollerindendir. Kartal ayrıca hâkimiyeti, otoriteyi, iyiliği, özgürlüğü, yiğitliği, asaleti, güneşi, talih ve bilginliği de temsil etmektedir. Kartal gelecekten haber veren kuş olarak da kabul edilmiştir (Kafesoğlu, 2000'den akt. Çatalbaş, 2011: 50; Çoban, 2015, 57). Armadaki kartal ayrıca Yenicami AK'nün güç arzusunda işaret etmektedir. Armada kullanılan beyaz renk temizliği, saflığı; siyah renk ise ciddiyet ve ağırbaşlılığ simgelemektedir (Çavdar, 2007).

\section{Sonuç}

Sporun en popüler türlerinden olan ve kitlesel, küresel ölçekte bir ilgiye haiz olan futbolun, bir kültür ve kimlik taşıyıcısı/aktarıcısı misyonu da vardır. Öyle ki futbol kulüpleri ulusal ve uluslararası müsabakalarda nasyonal misyonlar yüklenirken, kentsel ya da makro milliyetçilikler de yapmaktadırlar. Bununla birlikte kulüplerin geçmişleri, tarihsel misyonları hatta armaları dâhi başlı başına bir kimliği ya da kültürü sembolize edebilmektedir. Örneğin bu çalışma kapsamında gerçekleştirilen göstergebilimsel analizde KKTC K-Pet Süper Ligi'nde (2018-2019 sezonunda) mücadele eden ve Kıbrıs Türk Futbol Federasyonu bünyesinde olan futbol kulüplerinin Türklük bağlamında milli değerleri göz ettikleri ve armaları dolayımı ile aktardıkları söylenebilir.

Çalışmada gerçekleştirilen analizde görülmüştür ki, armalarda gözlenen baskın renkler genellikle Türklüğü simgeleyen kırmızı-beyaz ile yeşil ve sarı olmuştur. İncelenen toplam 16 armanın 4'ünde bariz ay-yıldız formu görülmektedir. Ay-yıldız formu 3 armada ise örtük olarak yer almaktadır. Ayrıca lacivert, mor ve siyah renkleri de kullanım yoğunluğu noktasında dikkat çekicidir. Spor ile özdeşleşen "meşale" görseli de birçok armada kullanılmıştır.

Çalışma kapsamında gerçekleştirilen analizde ayrıca Kuzey Kıbris K-Pet Süper Ligi'nde mücadele eden futbol kulüplerinin armalarında hayvan metaforlarından yararlandıkları da gözlenmiştir. Öyle ki armaların 1'inde güvercin, 1'inde kartal, 1'inde yunus yer alırken, aslan ve kaplan metaforları da armalarda dikkat çekmektedir. Bu metaforlar ile futbol kulüpleri güç, zafer ve kararlılık mitlerine dikkat çekmek istemişlerdir. Bu noktada Türklerin geçmişten bugüne güç, kudret, irade, zafer gibi bağlamlarda görsel ve yazılı olarak hayvan metaforlarından yararlandıklarını (Şişci, 2018) da belirtelim.
Ayrıca armaların 2'sinde yaprak görselinin yer alması da önemlidir. Yıllardır süren Kıbrıs Sorunu bağlamında barışa işaret eden yeşil renk ve yaprakların (defne) kullanımı, futbol kulüplerinin 1lımlı spor anlayışları ile barışa atfettikleri öneme gönderme yapmaktadır.

Bununla birlikte, futbol kulüplerinin çoğunun oldukça köklü kulüpler olduğu da görülmektedir. Öyle ki tüm armalarda kulüplerin kuruluş tarihleri yer almakta ve kulüpler köklü geçmişleri ile dikkat çekmektedir. Kulüplerin armalarındaki beyanlarına göre kuruluş tarihi noktasında en eski kulüp 1930 tarihi ile Çetinkaya TSK iken, en yeni kulüp ise 1975 tarihi ile Esentepe KKSK'dır. Kulüplerin çoğunun, 1940’lı ve 50'li yıllarda kurulmuş olduğu görülmektedir.

Sonuç olarak Kuzey Kıbrıs K-Pet Süper Ligi’nde mücadele eden futbol kulüplerinin armalarında Türklük noktasında (özellikle ay-yıldız formu ile kırmızı-beyaz renk kullanımı ile) önemli hassasiyetler taşıdıkları söylenebilir. Armalarda kullanılan hayvan metaforlarında futbol kulüpleri gibi Türklüğün gücü, kudreti ve asaleti de örtük olarak resmedilmiştir. Ezoterik mesajların verildiği ilgili kulüp armaları, Türkiye'nin yavru vatanı olan Kuzey Kıbrıs Türk Cumhuriyeti'nin milli kimliğini ve mevcudiyetini önemli ölçüde yansıtmaktadır.

\section{Kaynakça}

Agos Gazetesi. (2009). "Milliyetçiliğin ve cinsiyetçiliğin yeniden üretildiği alan: Futbol”, 24 Şubat 2009, URL: http://acikradyo.com.tr/arsiv-icerigi/milliyetciligin-vecinsiyetciligin-yeniden-uretildigi-alan-futbol.

Adîr, G., Adîr, V. \& Pascu, N. E. (2012). Logo design and the corporate identity, Procedia - Social and Behavioral Sciences 51 (2012): 650-654.

Ağar, S. (2006). Türk Spor İdaresinde Türkiye Futbol Federasyonu'nun Yeri ve İşlevi -Kurumsal İnceleme-, TBB Dergisi, Say1 63, ss. 271-320.

Altunay, E. (1999). “Ezoterizm Nedir?”, URL: http://www.hermetics.org/Ezoterizm\%20Nedir.html.

Badir, S. (2014). The Semiotic Hierarchy, URL: http://www.signosemio.com/hjelmslev/semiotichierarchy.asp.

Baş, M. (2008). Futbolda Taraftar ve Takım Özdeşleşmesi (Trabzonspor Örneği), T.C. Gazi Üniversitesi Sağlık Bilimleri Enstitüsü Beden Eğitimi ve Spor Anabilim Dalı, Doktora Tezi, Ankara.

Bayat, N. (2010). Şiirde Anlatım ve İçeriğin Dilbilimsel Boyutlar1, folklor/edebiyat 16 (61): 157-168.

Boydaş, O. (2017). Ezoterizm, Mu Uygarlığı ve $\mathrm{Mu}$ Kozmogonik Diyagramı, Kent Akademisi/Kent Kültürü ve Yönetimi Hakemli Elektronik Dergi, 10 (3): 338-350.

Boztaş, E. \& Düz, N. (2014). İkonografik ve İkonolojik Eleştiri Yöntemine Göre Tintoretto'nun 'İsa'nın Vaftizi” Adlı Eserinin Analizi, Uluslararası Sosyal Araştırmalar Dergisi, 7 (29): 319-329.

Buchanan, R. (1992). Wicked Problems in Design Thinking, Design Issues, 8 (2): 5-21. 
Calhoun, C. (2012). Milliyetçilik, 3. Baskı, Çev B. Sütçüoğlu, İstanbul Bilgi Üniversitesi Yayınları, İstanbul.

Cengiz, A. K. (2016). "Bİ(R)Yerli" Olmak: Anlatılar ve İmgeler Üzerinden Antakyalılık, T.C. Ankara Üniversitesi Sosyal Bilimler Enstitüsü Antropoloji (Sosyal Antropoloji) Anabilim Dalı Doktora Tezi, Ankara.

Cenikli, A., Dalkılıç, M., Yiğit, E. \& Bozkurt, V. (2017). Modern Futbolun Tarihi, Diyalektolog Ulusal Sosyal Bilimler Dergisi, Bahar 2017, Say1 14, ss. 53-63.

Churchward, J. (2015). Kayıp Kıta Mu, Çev. Pelin Tornay, İstanbul: Omega Yayın.

Cornell Maple Bulletin 103 (2007). Creating a Logo, by Tara Gustafson and Brian Chabot.

Çamdereli, M. \& Gürer, M. (2008). Futbolda görsel kimlik öğesi olarak kulüp armaları, İletişim kuram ve araştırma dergisi, Sayı 26, Kış-Bahar 2008, ss.135168.

Çatalbaş, R. (2011). Türklerde Hayvan Sembolizmi ve Din İlişkisi, TURAN-SAM Turan Stratejik Araştırmalar Merkezi Dergisi, 3 (12): 49-60.

Çavdar, I. (2007). "Renklerin Anlattıkları”, 28.07.2007, URL: http://blog.milliyet.com.tr/renkler-veanlattiklari/Blog/?BlogNo=54541.

Çoban, İ. (2015). Türk İkonografisinde Kartal Motifi ve Çağdaş Türk Resmine Yansımaları, idil, 4 (16): 57-80.

Devecioğlu, S., Çoban, B., Karakaya, Y. E. \& Karataş, Ö. (2012). Türkiye'de Spor Kulüplerinin Şirketleşmeye Yönelimlerinin Değerlendirilmesi, SPORMETRE Beden Eğitimi ve Spor Bilimleri Dergisi, 2012, X (2): 35-42.

Dobson, S. \& Goddard, J. (2001). The Economics of Football, Cambridge University Press.

Doğan, T. N. (2017). "Renklerin Anlamları ve Psikolojik Etkileri", 28.06.2017, URL: https://paratic.com/renklerin-anlamlari-ve-psikolojiketkileri/.

Doğru, C. (2008). Futbolda Rekabetçi Dengenin Yeniden Tesisi ve Futbol Emek Piyasasının Yeniden Düzenlenmesi: Ücret Tavanı Modeli, 2. Ulusal İktisat Kongresi/20-22 Şubat 2008.

Enes, Ö. (2011). Spor Ayakkabıların Teknik ve İşlevsel Değişim Yoluyla Gündelik Kullanıma Yönelik Tasarımı, T.C. Dokuz Eylül Üniversitesi Güzel Sanatlar Enstitüsü Tekstil Anasanat Dalı Sanatta Yeterlik Tezi, İzmir.

Erdoğan, İ. (2008). Futbol ve futbolu inceleme üzerine, Iletişim kuram ve araştırma dergisi, Sayı 26 Kış-Bahar 2008, ss.1-58.

Faste, T. \& Faste, H. (2012). Demystifying "Design Research": Design Is Not Research, Research Is Design, IDSA Education Symposium 2012, August 15, 2012, Boston.
Giulianotti, R. \& Armstrong, G. (2010). Sport, the military and peacemaking: history and possibilities, Third World Quarterly, 32, (3): 379-394.

Günay, M. (2016). Türkiye'de Spor Cemiyetlerinin Kuruluşu ve $\mathrm{Bu}$ Cemiyetlerin Etnik Amaçlarla Kullanılması, International Journal of Science Culture and Sport, August 2016: 4 (Special Issue 1), pp. 383 393.

Hacısoftaoğlu, İ., Akcan, F. \& Bulgu, N. (2012). Hayali Cemaatler Olarak Taraftar Toplulukları: Ankaragücü Taraftar Grupları Örneği, Spor Bilimleri Dergisi Hacettepe J. of Sport Sciences, 23 (4): 159-176.

Hardy, G. (2011). Smashing Logo Design: The Art of Creating Visual Identities, Wiley.

Hargrave, R. (2007). Football Fans and Football History: A Review Essay, Soccer \& Society, 8: 2-3, 240-249.

History of Football - The Origins - FIFA.com. (Erişim: Kasim 2018). URL: https://www.fifa.com/aboutfifa/who-we-are/the-game/index.html.

Howard, J. A. (2000). Social Psychology of identities, Annu. Rev. Sociol. 26: 367-93.

Hürriyet. (1997). "Semboller: Dünyanın ortak dili”, 12.08.1997, http://www.hurriyet.com.tr/gundem/sembollerdunyanin-ortak-dili-38011892.

International Year of Light 2015. (2015). Logo Use \& Identity Application Guidelines, URL: http://www.light2015.org.

İlkdoğan, H. (2017). Göstergenin Toplum Düzlemindeki Yeri: Toplumsal Göstergebilim, idil, 2017, Cilt 6, Sayı 39, Volume 6, Issue 39, pp. 3147-3164.

Kehily, M. J. (2009). What is identity? A sociological perspective. In: ESRC Seminar Series: The educational and social impact of new technologies on young people in Britain, 2 Mar 2009, London School of Economics, UK.

Khronos Group Logo Usage Guidelines. (May 2018). Proper Logo Usage, URL: https://www.khronos.org/files/legal/Khronos-LogoUsage-Guide.pdf.

Logo Design Basic. (Erişim: Ekim, 2018). http://www2.latech.edu/ dehall/STEMdiscovery/desig n/logo_lecture.pdf.

Meydan, S. (2009). Atatürk ve Kayıp Kita Mu, İstanbul: İnk1lap Yayınları.

Narcotta-Welp, E. M. (2016). "The future of football is feminine" : a critical cultural history of the U.S. women's national soccer team, PhD (Doctor of Philosophy) thesis, University of Iowa, 2016.

Nur, İ. H. (2013). Mesnevi'de Hayvan Karakterleri (Metaforları), AVKAE, 3 (1): 18-30.

Öney, G. (1992). Anadolu Selçuklu Mimari Süslemesi ve El Sanatları, İş Bankası Yayınları. 
Özbek, M. (1999). Cumhuriyetle Başlayan Antropoloji, Hacettepe Üniversitesi Edebiyat Fakültesi Dergisi, Cumhuriyetimizin 75. Y11 Özel Sayıs1, ss. 105-107.

Özdağ, S., Duman, S. \& Fişekçioğlu, İ. B. (2011). Popüler Kültür: Futbol Mu "Putbol" Mu?, Türkiye Kickboks Federasyonu Spor Bilimleri Dergisi, Volume: 4, Say1:1, ss. 11-22.

Özsoy, S. (2011). Spor Gazetelerinin Başlıklarında Militarist ve Şiddet İçerikli Metaforlar, e-gifder, Sayı:1, Mart 2011, ss. 88-114.

Papert, S. (1999). "Introduction: What is Logo? And Who Needs It?", Logo Philosophy and Implementation, Graphic design by Le groupe Flexidée(Logo Computer Systems Inc.

Pearson Brand Guidelines 2016. (2016). Logo, URL: https://www.pearson.com/content/dam/one-dotcom/one-dot com/global/Files/logos/Pearson_Guidelines_Logo.pdf.

Pontious, M. F. (2013). Planning Curriculum in Art and Design, Wisconsin Department of Public Instruction Tony Evers, PhD, State Superintendent, Madison, Wisconsin.

Saraçoğlu, H. (2007). Kuzey Afrika ve Asya Ülkelerinin Bayrakları Üzerine Bir İnceleme, ICANAS 38 (Uluslararası Asya ve Kuzey Afrika Çalışmaları Kongresi) Tarih ve Medeniyetler Tarihi, 10-15 Eylül 2007, VI. Cilt, ss. 2669-2684, 3135-3139, Ankara, 2012.

Soygüden, A., Barut, Y. \& İmamoğlu, O. (2016). Profesyonel Futbol Taraftarl ve Stadyum, Ed. Yahya Polat, 1. Bask1: Kasım 2016, PEGEM Akademi, Ankara.

Smith, D. A. (1992). Is there A Global Culture?. Intermedia, $20(4-5)$.

Şahin, M. Y. \& Tunçkol, H. M. (2010). İşçi Hareketlerinin Futbolun Tarihsel Gelişim Sürecine Etkisi, TSA / Y11: 14, S: 1, Nisan 2010.

Şahin, M. Y., Yenel, F. \& Çolakoğlu, T. (2010). Spor ve Milliyetçilik Etkileşimi: Ulusal Kimlik Oluşturmada Sporun Yeri ve Önemi, Uluslararası Insan Bilimleri Dergisi, 7 (1): 1244-1263.

Şahindoğan, B. (2017). "Mitolojinin dili doğanın simgeleriyle oluşmuştur”, 22.01.2017, URL: https://www.evrensel.net/haber/305033/mitolojinindili-doganin-simgeleriyle-olusmustur.

Şişci, F. (2018). Türk Mitolojisinde Güvercin Motifi ve Çağdaş Türk Resminde Temsili, idil, 7 (41): 47-53.

Taura, T. \& Nagai, Y. (2009). A Definition of Design and Its Creative Features, In: Proceedings of International Association of Societies of Design Research, URL: http://www.research.kobe-u.ac.jp/eng-mechdesign/taura/img/taura_pub/72.pdf.
Taylor, M. (2007). Footbal, Migration and Globalization, www.idrottsforum.org, 2007-03-14.

The Olympic Studies Centre. (2017). Osc Reference Collection, Football History of Football at the Olympic Games, 19.10.2017.

Topçu, Ö. (2017). Kurumsal Kimlik Oluşturmada Bir Logonun Markaya Etkisi, e-Journal of New Media / Yeni Medya Elektronik Dergi-eJNM, 1 (2): 157-163.

Türkiye Futbol Federasyonu Kuruluş ve Görevleri Hakkında Kanun, Kanun Numarasi: 5894, Kabul Tarihi: 5/5/2009.

Ulrich, K. T. (2011). Design Is Everything?, J PROD INNOV MANAG 2011;28:394-398, r 2011 Product Development \& Management Association.

Ulun, C. \& Yetim, A. A. (2016). Türkiye'deki Futbol Kulüplerinin Sportif Başarı Düzeyi ve Mali Yapı Açısından Rasyo (Oran) Analizi İle İncelenmesi: Galatasaray ve Fenerbahçe Örneği, Sportif Bakış: Spor ve Eğitim Bilimleri Dergisi, 3 (1), 70-81, 2016.

Ustakara, F. \& Aydemir, M. (2016). Spor Kulüpleri ve Marka: İletişim Fakültesi Öğrencileri Örneğinde Bir Araştırma, Journal of Yasar University, 2016, 11/41, 16-29.

Üzmez, S. (2016). "Balığın Simgesel Anlamları", 14.11.2016, URL: https://www.google.com.tr/amp/m.milliyet.com.tr/am p/yazarlar/sureyya-uzmez/baligin-simgesel-anlamlari2344352/.

Vermaas, P. E. (2014). Chapter 2, Design Theories, Models and Their Testing: On the Scientific Status of Design Research, A. Chakrabarti and L. T. M. Blessing (eds.), An Anthology of Theories and Models of Design.

Yegen, C. (2018). Siyasal İletişim, Propaganda ve Ulusal Kimlik, Kriter Yayınları, İstanbul.

Yılmaz, L. (2016). Bizans Sanatında Yunus (Jonah) ve Yunus Sembolü Üzerine, Uluslararast Sosyal Araştırmalar Dergisi, 9 (44): 757-761.

Yılmaz, M. \& Saymalı, M. (2013). Göstergebilimsel Yöntem Işı̆̆ında Otomotiv Firmalarının Amblemlerinin Çözümlenmesi, İstanbul Ticaret Üniversitesi Sosyal Bilimleri Dergisi, Y1l:12 Sayı:23 Bahar 2013 s.167179.

Zamenopoulos, T. \& Alexiou, K. (2007). Towards an anticipatory view of design, Design Studies 28 (2007) 411-436.

Zelyurt, M. K. (2013). Dünyanın Çeşitli Bölgelerinde Etnik Gerilimler Bağlamında Futbol, Journal of the Human and Social Science Researches, 2 (2): 179-214.

http://misirgizemleri.blogspot.com/2008/08/ezoterizme-greaslan-neyin-semboldr-1.html., Ezoterizme Göre Aslan Neyin Sembolüdür? - 1, 2008. 